\title{
Problems of Improving Performance Budgeting in the Russian Constituent Entities under Digital Economy
}

\author{
T.M. Kovaleva ${ }^{1}$, L.N. Mulendeeva ${ }^{1}$ and A.G. Glukhova ${ }^{1, *}$ \\ *Corresponding author, E-mail: hecate1@ mail.ru \\ ${ }^{1}$ Samara State University of Economics, Samara, Russia
}

\begin{abstract}
A complex process of performance budgeting transition requires restructuring the system of state administration and organization of the budget process, strengthening the autonomy and responsibility of ministries and departments involved in the implementation of government programs.

This paper aims at further development of scientific provisions of performance budgeting in the constituent entities of the Russian Federation, analysis of problems and development prospects.

Improving performance budgeting in the digital economy implies the development of an information infrastructure, namely, an effective system of Internet resources in order to provide citizens with relevant information on the state programs implementation and their efficiency evaluation.

Methodological guidelines for evaluation of performance budgeting efficiency in the RF constituents were developed in the course of this study.

The results of the study could be applied to regional performance budgeting improvement. The findings could also allow government bodies to increase the efficiency of budgeting.
\end{abstract}

Keywords: budget policy, digital economy, digitalization, expenditure planning, program-target method, public finances.

\section{Introduction}

The development of the economy and social sphere in our country under modern conditions requires the improvement of budget planning and involves the development of procedures based on the management by objectives method. This is confirmed by the fact that one of the key tasks of Russian budgetary policy is to expand the application of state programs to budget planning.

The experience of various countries has demonstrated increased efficiency of budgetary expenditures as the result of performance budgeting (PB) application, which involves the implementation of public expenditures in order to achieve specific quantitative results stipulated in the relevant government programs. The United States, France, Germany, Norway, the Czech Republic and some other countries have achieved some success in this regard and their practice experience could be useful in introducing new budget planning methods in Russia.

Performance budgeting application in the Russian Federation should be consistent with the development objectives of the digital economy, which is characterized by the use of digital data in all spheres of social and economic activity. Among the five main directions for the digital economy development, information infrastructure is of particular importance for improving performance budgeting. 


\section{Problem Statement}

Analysis of the theory and practice of performance budgeting showed that there are still many unsolved problems in this area. In particular, the content of the performance budgeting is not defined; there are no studies characterizing the stages of performance budgeting; factors affecting the development of the PB are not classified. There are no uniform methodological approaches to evaluating the efficiency of performance budgeting. All of the above indicates that there is the urgent need for further research on improving performance budgeting in modern conditions.

\section{Research Questions}

This study therefore set out to examine methodological background of performance budgeting and to determine its content. Also this research seeks to reveal efficiency evaluation problems of PB in the constituent entities of the Russian Federation under modern conditions. The analysis of PB in Samara region is to be conducted in the study. The paper also attempts to improve methodological approach to efficiency evaluation of performance budgeting.

\section{Purpose of the Study}

The specific objective of this study was to develop scientific basis for performance budgeting and to provide practical recommendations for its improvement taking into account modern conditions and the requirements of the digital economy.

\section{Research Methods}

The approaches to research adopted for this study were the following ones: theoretical (dialectical logic, methods of scientific abstraction); diagnostic (analysis, modeling); empirical (comparison and generalization, grouping); experimental (observation and practical calculations); methods of mathematical statistics and graphical images of the results. The experimental base of the research is the state programs of the Samara region.

\section{Findings}

\subsection{Reviewing the literature}

Previous economic research reduced the essence of the management by objectives method to linking the objectives and resources of the plan using programs. This method represents the allocation of budgetary resources, aimed at obtaining meaningful, quantifiable results. The allocation should be accompanied by monitoring and control of the goals achievement process, planned results, as well as ensuring the quality of budget planning.

The mid-XX century gave rise to performance method, which clearly manifested itself in budgeting model that was performance-based. Each state, including Russia, adapts this model to its own conditions of socio-economic development, introduces its own elements into it. In our opinion, the term "performance-based budgeting" corresponds to the current stage of development of budget planning in Russia. 
The most common definitions of performance-based budgeting given in scientific sources are considered below.

1. Linking plan objectives with resources using programs [1].

2. A method aimed at developing a plan based on social needs assessment, defining economic development goals, searching for resources, as well as the best ways and means to achieve them [2].

3. A tool that may have the ability to contribute to performance improvement in economic entities [3].

4. A complex process where the use of decision support systems for processing quantitative data and developing analytical solutions is practically pervasive [4].

5. A way to address circumstances where there are multiple objectives (usually conflicting ones) and the optimization of an objective is always done at the expense of others. It consists in quantifying the deviation from these goals, formulating an objective function for each of the goals, and then to seek a solution that minimize the deviations of these objective functions from the predefined goals [5].

6. A process of establishing of the connection between the result of a period and the required funds [6].

7. A method to improve budget expenditure efficiency, which is an essential prerequisite for public authorities and municipal bodies to be workable [7].

8. A public expenditure management mechanism, i.e. expenditures related to financing activities of public sector organizations, financing the procurement of goods and services, government orders to produce public goods, financing social cash and in-kind payments to society. It is an important part of the budget policy and the mechanism of the public sector [8].

9. A mechanism for directing budgetary resources to achieve socially significant and quantifiable results of activities while simultaneously monitoring and controlling the achievement of the intended goals and results, as well as ensuring the quality of internal departmental budget planning and financial management procedures [9].

Thus, the term 'performance-based budgeting' embodies a multitude of concepts with the general idea of linking the objectives of the plan with resources using programs.

In finance the term "budgeting" is defined as the process of forming budgets and subsequent control over their execution. It is almost certain that budgeting in public finance could be explained as budget planning not limited with budget formation but assuming further analysis and control of compliance with planned and actual financial indicators.

In practice posting updated information about the state programs implementation and efficiency evaluation on the relevant ministries' websites could promote an effective control implementation. Thus, any personal computer user could employ digital economy infrastructure to have an access to the information on budget expenditures.

\subsection{Results}

Performance budgeting is targeted above all to improving the efficiency and effectiveness of state budget resources use. The state program is one of the tools to achieve this goal. Performance budgeting is characterized by the distribution of almost all government spending for implementation of its ongoing programs. The goal of each specific program is closely connected with the certain result of the relevant authority's performance. That requires increased autonomy and increased responsibility of the relevant ministries and departments [10]. Performance budgeting expands the functionality of monitoring program implementation through the use of modern information technologies, thereby increasing the efficiency of managing state and municipal finances.

Literature analysis suggests that currently there has been no unified approach to assessing the efficiency of state and municipal programs. In the PB process, the priority is given to the planning of budget expenditures with the achievement of specified results 
taken into account. The cost of resources for programs implementation and the results obtained, expressed by various indicators, have different units of measurement. That, in turn, causes the complexity of programs efficiency assessment. Ultimately, the efficiency of the program is evaluated by the ratio of its target indicator achievement degree to the completeness of funding. And the index method allows balancing the effect of measurement units. A similar approach has found its application in Samara region [11].

The existing methods of the RF state programs efficiency assessment has tended to focus on calculation of procedures performance indicators: the degree of planned results achievement and the degree of budgetary resources utilization that had been allocated for the financial support of programs. Those methods fail to calculate the programs performance efficiency as the correlation of the results obtained with the costs. Thus, it is obvious that, while assessing the performance budgeting efficiency with existing methods, it is impossible to determine the actual value of budget savings resulting from the implementation of state programs. A more systematic approach applied in this paper determines three basic directions for regional budgeting. Within those directions some procedures are suggested.

A. Logical structure of programs. The improvement of this direction of PB should be ensured by the following measures.

1. Achieving consistency of state programs with the documents of strategic planning of the territory.

2. A clear, unambiguous definition of state programs objectives.

3. Compliance of tasks with the necessity and sufficiency requirements to achieve them.

4. Definition of program sub-goals for each participating ministry.

5. The correlation of programs' goals, objectives, activities and target indicators.

6. Reflection of the relationship with related state programs.

7. Assignment of responsibility for the of program implementation results to the relevant ministries.

B. Financial support of programs.

1. Taking into consideration budget resource.

2. Determination of the optimal budget allocations for the implementation of state programs.

3. Availability of extra budgetary sources of financing.

4. Revision of target indicators values in accordance with changes in funding.

5. Development of alternative options for financial support of programs.

C. Control over the efficiency of budget spending.

1. Development of an effective system for assessing the effectiveness of budget expenditures.

2. Auditing the efficiency of programs.

3. Expanding the regional ministry functions for financial management to monitor the efficiency of budget spending.

4. Improving the information infrastructure of performance budgeting with the advances of the digital economy.

Researchers of performance budgeting have not treated the issue of calculation the amount of budget expenditures on state programs per capita in much detail. This index is however employed in this research to evaluate the efficiency of performance budgeting. It is stated that the index could become an integral criterion that characterizes the minimum acceptable level of state program funding, reflecting the overall feasibility of budget expenditures for program implementation.

The "fiscal capacity of programs" index is suggested to characterize the amount of the RF constituent entity's budgetary resources allocated for financing a specific state program per capita. 
Thus, the formula for calculating the fiscal capacity of programs in the region is as follows:

$$
\mathrm{FCP}=\mathrm{AFSSP} / \mathrm{NR} \text {, }
$$

where, FCP - fiscal capacity of programs in the RF constituent entity, rub. /person;

AFSSP - amount of fiscal support for state programs, rub.;

$\mathrm{NR}$ - number of residents in the RF constituent entity for the period, people.

The significance of calculating the programs' fiscal capacity arises from its comparison with similar indices of other constituent entities in the Russian Federation, especially with the index of fiscal capacity of programs in the whole country.

Fiscal capacity coefficient value in the region could be in the range from 0 to 1 . Thus, the closer the coefficient is to 1 the higher the fiscal capacity of the RF constituent entity programs and the higher is the state programs efficiency and performance budgeting respectively.

Table 1. Types of the RF regions according to fiscal capacity of implemented programs

\begin{tabular}{|l|c|l|}
\hline \multicolumn{1}{|c|}{ Type of region } & $\begin{array}{l}\text { Threshold values of programs' } \\
\text { fiscal capacity }\end{array}$ & $\begin{array}{l}\text { Regional } \\
\text { programs } \\
\text { efficiency }\end{array}$ \\
\hline High income & $0,8-1$ & High \\
\hline Middle income & $0,4-0,7$ & Moderate \\
\hline Low income & $0-0,3$ & Low \\
\hline
\end{tabular}

Source: compiled by the authors.

Estimating the ratio of programs' fiscal capacity makes it possible to assign a region to a certain type, which is characterized by a corresponding performance in the use of budget resources for the implementation of state programs. A typology of regions according to the level of their fiscal capacity was developed (Table 1).

On the basis of the proposed methodology, the type of region for Samara region was determined in terms of the state programs' fiscal capacity (Table 2).

Table 2. Identification of the Samara region according to its fiscal capacity for state programs coefficient

\begin{tabular}{|l|c|l|c|}
\hline \multicolumn{1}{|c|}{ Program } & $\begin{array}{l}\text { Fiscal capacity } \\
\text { value }\end{array}$ & Region type & $\begin{array}{l}\text { State program } \\
\text { performance }\end{array}$ \\
\hline $\begin{array}{l}\text { Healthcare } \\
\text { development }\end{array}$ & 0 & Low income & Low \\
\hline $\begin{array}{l}\text { Education } \\
\text { development }\end{array}$ & 0 & Low income & Low \\
\hline $\begin{array}{l}\text { Residential } \\
\text { development }\end{array}$ & 1 & High income & High \\
\hline Sport development & 0,7 & Middle income & Moderate \\
\hline $\begin{array}{l}\text { Agricultural } \\
\text { development }\end{array}$ & 0 & Low income & Low \\
\hline
\end{tabular}

Source: compiled by the authors.

Overall, taken together, these results indicate that it is necessary to increase the efficiency of Samara Region state programs in the domains of health, education and agriculture. 


\section{Conclusion}

As mentioned in the literature review, the basis of the budget planning methodology at its current stage of development is performance budgeting, which arose from the programtarget budget planning method. Analysis of the performance budgeting content allowed formulating its more exact definition. Currently, a unified methodological approach to assessing the efficiency of PB through state programs has not been developed in Russia. The existing methods are mainly focused on the calculation of performance indicators and do not allow determining the actual amount of budget savings resulted from the implementation of state programs.

PB development in the Russian Federation constituent entities takes place in a digital economy that imposes requirements on the process of forming, processing and storing information on the implementation process and assessing the efficiency of government programs.

In order to improve the methodological approaches to evaluating the efficiency of performance budgeting in the Russian Federation constituent entities, it is proposed to use the indices of "programs' fiscal capacity" and "programs' fiscal capacity coefficient". The evidence from this study suggests that application of those indices makes it possible to assign a region to one of three types, which are characterized by a corresponding performance of using budgetary resources for implementation of state programs.

\section{References}

1. P. Zvyagintsev, Program-targeted planning method as the basis for creating a new industrialization of Russia. Questions of Economics and Law, 63, 41-47 (2013). [in Rus.].

2. N. Shash, A. Borodin, A. Tatuev, Problems of transition to the program budget: New challenges of the budget policy of Russia. Terra Economicus, 11(4-2), 145-152 (2013). [in Rus.].

3. G.L. Tănase, An analysis of the existence of a link between budgets and performance in economic entities. Procedia Economics and Finance, 32, 1794-1803 (2015).

4. L. Zamfirescu, C.-B. Zamfirescu, Goal programming as a decision model for performance-based budgeting. Procedia Computer Science, 17, 426-433 (2013).

5. K. Mukherjee, A. Bera, Application of goal programming in project selection decision - a case study from the Indian coal-mining industry. European Journal of Operational Research, 82(1), 18-25 (1995).

6. G. Lytvynchenko, Programme management for public budgeting and fiscal policy. Procedia Social and Behavioral Sciences, 119, 576-580 (2014).

7. A. Volkova, A review of government programs. Procedia Economics and Finance, 27, 484-493 (2015).

8. F. Germann, G.L. Lilien, A. Rangaswamy, Performance implications of deploying marketing analytics. International Journal of Research in Marketing, 30(2), 114-128 (2013).

9. N. Manning, N. Parison, International public administration reform: Implications for the Russian Federation. Washington, D.C.: World Bank (2003).

10. A. Tushov, Targeted programs in the system of state regulation of the economy. Economic Sciences, 3(88), 151-154 (2012). [in Rus.].

11. L. Mulendeeva, Program-targeted budgeting: Content and role in modern conditions. Economy and Entrepreneurship, 9(1), 1040-1043 (2017). [in Rus.]. 